\title{
Questions of Organisation, Portraits and Everyday Life in Vienna, 1814-1815. La Garde-Chambonas about the Congress of Vienna
}

\author{
prof. István MAJOROS
}

\author{
Bölcsészettudományi Kar, Eötvös Loránd Tudományegyetem \\ Faculty of Humanities, Eötvös Loránd University \\ Múzeum krt. 6-8, 1088 Budapest, Hungary \\ majorosi49@t-online.hu
}

"The Vienna settlement of 1815 has been ranked with the Peace of Westphalia (1648), the Peace of Utrecht (1713), and the Peace of Paris (1919) as one of the four most significant international agreements in the history of modern Europe." - writes Charles Breunig about the Congress of Vienna. ${ }^{1}$ The author is right, because the nineteenth century was more peaceful ${ }^{2}$ than any predecessor in the history of Europe due to the Congress of Vienna. After the Napoleonic Wars, the congressmen re-established the European balance of power for the stability and peace of the continent. By the help of the Holy Alliance and by the Quadruple Alliance ${ }^{3}$ the great powers guaranteed the measures accepted in Vienna and the political and the territorial status quo in Europe created by the Congress. ${ }^{4}$ The European balance of power was one of the principles of the settlement in Vienna represented first of all by Metternich. ${ }^{5}$ In the opinion of the chancellor of Austria, Central Europe represented the main element of the new settlement because he did not want to restore the Holy Roman Empire and he did not want to create a nation state in Germany or

1 BREUNIG, Charles: The Age of Revolution and Reaction 1789-1850, New York - London 1977, 121.

2 There were no wars between the great powers in these periods 1815-1854 and 1871-1914. And in 1854-1870 there were limited wars between the great powers but these wars did not transformed Europe. It's about the Crimean War (1853-1856), the Italian War (1859), the Austro-Prussian War (1866), and the Franco-Prussian War (1870-1871). SCHROEDER, Paul W.: International politics, peace, and war, 1815-1914, in: The Nineteenth Century Europe 1789-1914, BLANNING, T. C. W. (ed.), Oxford 2000, 158.

3 The Holy Alliance was signed in Paris on 26 September 1815 by the Russian Tsar Alexander I, the Austrian Emperor, Franz I and the Prussian King, Frederick William III. In espousing the idea of the Holy Alliance Alexander I was influenced by the Pietist mystic Baroness Barbara von Krüdner. The European rulers adhered to this alliance with the exception of the future George IV of Great Britain as prince regent, the Pope Pius VII and the Ottoman sultan, Mahmud II; the latter because he was not a Christian. In the framework of the Holy Alliance the three monarchs wanted to act as Christian brothers to protect religion, peace and justice. The Quadruple Alliance was signed in Paris on 20 November 1815 by the victors of Waterloo: Great-Britain, Russia, Austria and Prussia.

4 SCHROEDER, 2000, 158-161; SCHROEDER, Paul W.: The Transformation of European politics 1763-1848, Oxford 1994, 517.

5 The representatives of Russia, Great Britain, Austria and Prussia met in Chaumont and signed a treaty on 1 March 1814. They agreed that one of the main goals of the treaty was to maintain the balance of power in Europe. And they pledged to remain united for twenty years after signing this treaty. So Chaumont is important for the principle of the balance of power and also for the Quadruple Alliace. BREUNIG, 122; URBÁN, Aladár (ed.): Nyugat-Európa és Amerika 1789-1918. Új - és legújabbkori történeti szöveggyüjtemény 1/1, Budapest 1970, 122-123. 
in Italy. He was against nationalism, against this subversive idea that caused wars between 1792 and 1815 in Europe. That's why he wanted the representatives of the great powers in Vienna to accept his Mitteleuropa-plan: to establish a confederation in Germany and to create a divided and fragmented Italy under the influence and the leadership of Austria. This plan was accepted and Metternich created a Central Europe of 65 million people under the authority of the Habsburg dynasty. In the first part of the century, Metternich's Mitteleuropa became a bastion against France and the revolutions. ${ }^{6}$

The second guiding principle of the settlement was legitimacy. Charles Maurice de Talleyrand-Périgord, the chief negotiator of France in Vienna was the most important representative of the restored House of Bourbon. This dynasty was restored not only in France but also in Spain and in the Kingdom of the Two Sicilies. And one of the tasks of the peacemakers of Vienna was to restore not only the Bourbons but all legitimate rulers to their thrones in Europe. ${ }^{7}$

In 1814-1815 Vienna became the capital city of Europe. Why Vienna? The first Peace Treaty of Paris on 30 May 1814 decided on this issue: according to the final article of the treaty the interested powers would send their representatives to Vienna within two months to debate and arrange the fate of Europe after the Napoleonic wars. The two months had expired on 30 July but the Congress did not begin. In the meantime, three monarchs, the Russian tsar, Alexander I, the Austrian emperor, Francis I and the Prussian King, Frederick William III went to London to ask for the assistance of the Regent and the Tories against France and Castlereagh. That's why the starting date of the Congress was postponed to 30 September. Vienna was chosen by the great powers because of its central position in Europe and because of the participation of the Habsburg Empire in five coalitions against France and Napoleon. We must not forget Metternich's role in the work of the Congress. In 1814 he was an experienced diplomat: he had influenced the foreign policy of Austria since 1801. First he served the Hapsburg Empire as a minister in Saxony, then in Prussia between 1803 and 1805; in 1806 he became ambassador in Paris and in 1809 he was appointed foreign minister. During the Congress, he represented Austria in the diplomatic negotiations. ${ }^{8}$

The organizers wanted the Congress to last only four weeks to confirm the first Treaty of Paris, but we know well that it lasted nine months from September 1814 to June 1815. The Congress was not well prepared for the negotiations. Talleyrand writes in his letter of 25 September 1814 to Louis XVIII, the French King, from Vienna that nothing was decided

\footnotetext{
6 As for the principle of the balance of power, Metternich was influenced by his professors, Christophe Wilhelm von Koch at the University of Strasbourg and Nicholas Vogt at the Mainz University. We must not forget the role of Friedrich von Gentz, the adviser of Metternich in Vienna and the secretary general for the Congress. DROZ, Jacques: L'Europe centrale. Évolution historique de l'idée de "Mitteleuropa", Paris 1960, 42-50; ORMOS, Mária - MAJOROS, István: Európa a nemzetközi küzdőtéren. Felemelkedés és hanyatlás 1814-1945, Budapest 1998; BÉRENGER, Jean: Histoire de l'Empire des Habsbourg 1273-1918, Paris 1990, 551; PONTEIL, Félix: Histoire général contemporaine. Du milieu du XVIlle siècle à nos jours, Paris 1973.

7 GILDEA, Robert: Barricades and Borders. Europe 1800-1914, Oxford 2003, 59; BREUNIG, 129.

8 BREUNIG, 126; BOURGEOIS, Emile: Manuel historique de politique étrangère, tome II. Les révolutions (17891830), Paris 1933, 551-552; BÉRENGER, 546-547; CAPEFIGUE, Baptiste: Le congrès de Vienne dans ses rapports avec la cirsconscription actuelle de l'Europe: Pologne, Cracovie, Allemagne, Saxe, Belgique, Italie, Suisse, 1814-1846, Paris 1847, 19-20.
} 
about how the Congress would work. ${ }^{9}$ Referring to a secret article of the first Peace Treaty of Paris, the representatives of Russia, Austria, Great Britain and Prussia wanted to arrange the territorial questions and other important affairs. They sent an official statement about that to the French legation on 22 September. Talleyrand, arriving in Vienna on 23 September, was against this project in his answer. He proposed to the four great powers to create a committee of Eight with the participation of Great Britain, Russia, Austria, Prussia, France, Spain, Sweden and Portugal, so with the powers which had signed the Peace Treaty of Paris on 30 May 1814. Talleyrand was supported in this question by lord Castlereagh and finally Metternich accepted this proposition and the Committee of Eight was working under his presidency. ${ }^{10}$ Beside this committee, there were particular committees dealing with special affairs. The main issues of the Congress were: Poland, Saxony, Germany, Italy, Switzerland and the Kingdom of Netherlands. Alexander I was the only ruler who took part personally in the negotiations.

The rulers of the great powers arrived in Vienna on 25 September. There was not an official opening of the Congress, and the diplomats began to work on 1 November $1814 .{ }^{11}$ But the balls began at the end of September. According to contemporaries the Congress spent too much time on festivities. This is not true, because the diplomats worked hard. In spite of this, the contemporaries and the posterity know well the famous phrase of Prince of Ligne: "Le Congrès ne marche pas, il dance."12

This study does not want to deal with the main issues of the Congress, with how the diplomats redrew the map of Europe. We want to present the everyday life in Vienna during the Congress based on the book of La Garde-Chambonas. Who was this French aristocrat? In the preface of the book comte Fleury ${ }^{13}$ presents him.

Auguste-Louis-Charles de la Garde, literary man and poet, ${ }^{14}$ was born in Paris in 1783. His mother died after his birth and his father also died not much later. ${ }^{15}$ The marquis de Chambonas, the head of the family, brought up the orphan La Garde and considered him as his second child. ${ }^{16}$ In 1801 Auguste de la Garde went to Paris to Mme Récamier who helped his education. Due to his useful links he could go to Rome where he met Prince of

9 Correspondance inédite du prince de Talleyrand et du roi Louis XVIII pendant le Congrès de Vienne publiée sur les manuscrits conservés au dépôt des Affaires étrangères avec préfaces, éclaircissements et notes par M. G. PALLAIN, Paris 1881, No. 1: Letter of Talleyrand to Louis XVIII, Vienne, 25 September 1814, 4. (hereinafter only as Correspondance inédite).

10 BREUNIG, 123; Correspondance inédite, No. 3: Letter of Talleyrand to Louis XVIII, Vienne, 4 October 1814, 12; CAPEFIGUE, 26-28.

11 There was a meeting on 8 October 1814 at Metternich and here they decided to prorogue the Congress to 1 November. BOURGEOIS, 561.

12 The Congress does not move forward, it dances. La GARDE-CHAMBONAS, Auguste Louis Charles de: Souvenirs du Congrès de Vienne 1814-1815 publiés avec introduction et notes par le Comte Fleury, Paris 1901, 370.

13 Napoleon-Maurice-Émile Fleury (1856-1921), historian, publicist. He founded the review "Le carnet historique et littéraire". He has written, "La société parisienne de nos jours", under pseudonym, Jean d'Agrève.

14 Some works of La Garde-Chambonas: "Coup d'oeil sur le Royaume de Pologne" (Warsaw, 1818), "Brighton, Les monuments grecs de la Sicilie" (Munich, 1820), "Voyage en Angleterre" (1830), "Voyage dans quelques parties de l’Europe" (London, 1828).

15 His father was a captain of dragoons and knight.

16 He became minister of Louis XVI in 1792, replacing Dumouriez. 
Ligne who became his protector. Prince of Ligne invited him to Vienna. Then from this city he went to Russia, to Saint-Petersbourg. In 1810 he published his poems that proved to be a success. After that count Félix Potocki, a Polish aristocrat, invited him to Poland. Here he translated the poem of Stanislaw Trembecki, ${ }^{17}$ Sophiowka, in French that was dedicated to Sophia, ${ }^{18}$ the wife of Count of Potocki. In 1830 La Garde published a poem about "Funérailles de Kosciusko" and the Senate of Cracow declared him a Polish citizen. His book about the Congress of Vienna was first published in 1820. La Garde's memoir is not a great revelation about the Congress, the diplomatic negotiations - remarks count Fleury. But the book is very interesting because it is full of anecdotes, portraits about rulers, wellknown ladies and forgotten persons. ${ }^{19}$ How can we depict the life in Vienna in 1814-1815? We try to answer to this question using La Garde's book.

In Vienna, the foreigners numbered about one hundred thousand during the Congress. ${ }^{20}$ All the rulers of the Nordic countries went to Vienna. The Western and the Southern countries sent the most important notabilities. ${ }^{21}$ The consequence of this situation was for Francis I, the Austrian Emperor, to entertain the delegates of the European countries. "In the Hofburg itself he (the Emperor) was obliged, day and day out, to entertain an Emperor, an Empress, four Kings, one Queen, two Hereditary Princes, three Grand Duchesses and three Princes of the blood. Every night dinner at the Hofburg was led at forty tables; special liveries and carriages were provided for all the royal guests; the horses at the stable numbered no less than 1,400. Each monarch or head of family had brought with him a crowd of chamberlains and equerries, and royal consorts were attended by mistresses of the robe and ladies-in-waiting ... In order to amuse this horde, the Emperor Francis had appointed miscellanous visitors from his court officials a Festivals Committee who were driven to distraction by the task of inventing new forms of amusement and by the excruciating problems of precedence." 22 In La GardeChambonas' opinion, during a ball they could arrange territorial questions, during a dinner they could solve an indemnity. ${ }^{23}$ Accommodation was not cheap in Vienna. For example lord Castlereagh, the representative of Great Britain and the leader of the British diplomacy paid five hundred livres sterling for a month. At that time this was exceedingly expensive. ${ }^{24}$

17 Stanislaw Trembecki (1739-1812), Polish poet, well known in Europe. In 1765 he began a seven-year journey in Europe. He was in Paris, Vienna, Karlsbad, later in Rome and Berlin. He started a new trend in political poetry in the Polish literature.

18 She was born in a Greek family of Constantinople. She was a very beautiful woman and an ideal of beauty of this age. Her first husband was Count of Witt, Grand pensionary of Holland and he was in the service of Russia. One day Félix Potocki met the Count and the Countess of Witt and he fell in love with the Countess. Soon the Countess of Witt, the beautiful Sophie, became Countess of Potocki. Felix Potocki paid 2,000,000 forint to the Count of Witt for the divorce.

19 FLEURY, Maurice: Notice sur Le Comte Auguste de La Garde-Chambonas, in: Souvenirs du Congrès de Vienne 1814-1815 publiés avec introduction et notes par le Comte Fleury, LA GARDE-CHAMBONAS, Auguste Louis Charles de, Paris 1901, VII-XV.

20 At the beginning of the 19th century Vienna numbered about 250 thousand people. MAJOROS, István: Fejlődési utak a 19. századi Európában I. A gazdaság átalakul, Pécs 1995, 18.

21 LA GARDE-CHAMBONAS, 3.

22 NICOLSON, Harold: The Congress of Vienna: A Study of Allied Unity, 1812 -1822, New York 1946, 159-160. Quoting by BREUNIG, 124-125.

23 LA GARDE-CHAMBONAS, 2.

24 Ibidem, 7. 
The inhabitants of Vienna seemed to be proud of seeing their city chosen as centre of this Congress. We have to go back to the beginning of the sixteenth century to find a similar meeting of the crowned heads: in 1515, Maximilian I, Holy Roman Emperor had received the Jagellonian kings, Sigismund I of Poland, Ladislaus II of Hungary and Bohemia and this was the first Congress of Vienna. ${ }^{25}$ The second one was full of interesting personalities and we present some of them.

\section{Portraits}

For Auguste de La Garde-Chambonas the most important person in Vienna was the Prince of Ligne. ${ }^{26}$ We mentioned already his famous saying: "Le Congrès ne marche pas, il dance." 27 In 1814 he was seventy-nine years old. As a young man he served Austria and participated in the Seven Years War (1756-1763) and in the War of Bavarian Succession (1778-1779). He became a councillor of Joseph II, the Austrian Emperor. Thanks to his military services the Prince of Ligne became Field marshal. He travelled a lot. He was in Italy, in Switzerland and in 1780s in Russia. In 1787 he accompanied Catherine II to the Crimea and received here a landed estate from her. Later he devoted himself to literary work. He published his writings in French and German. ${ }^{28}$ In Vienna he was well known also by the rulers. When August de la Garde-Chambonas was for the first time in Vienna in 1807, he was received by the Prince of Ligne, who introduced him to the imperial court as his cousin. La GardeChambonas arrived in the capital of Austria at the end of September 1814 and his first visit led to the prince. "You will see here great things. Europe is now in Vienna" - the prince told him. And he added: "A general and lasting peace will be concluded here...the pleasure will conquer the peace." 29 The Prince of Ligne took La Garde-Chambonas to the balls where he was his guide. He knew well the European aristocracy. La Garde presents the house of the prince in Kalemberg, ${ }^{30}$ the hotel de Ligne, and in it his library where a sort of disorder reigned: in one corner there were the books of Montesquieu, one of the works of Rousseau was half-opened, and on the other side there were love-letters, poems, etc. There was also a writing table. "Here I commit my thoughts to paper in order not to forget them." He told him about his way of writing. ${ }^{31}$ La Garde met some interesting statesmen at the Prince, for example Nowosiltzoff, a councillor of the Tsar and the member of the provisional government in Warsaw. He was preparing a constitution for Poland. In the meantime, Count Arthur Potocki, a Polish nobleman, the young friend of Ligne arrived.

25 LA GARDE-CHAMBONAS, 26. Maximilian and the Jagellonian kings arranged marriages and due to these agreements the Habsburg House obtained the throne of Hungary and Bohemia in 1526.

26 Charles Joseph, Prince of Ligne was born in Brussels in 1735. The Prince had three daughters, princess Clary, countess Palffy and baroness Spiegel. His sons were Charles and Louis.

27 LA GARDE-CHAMBONAS, 370. Footnote 11.

28 Under this title: "Mélanges militaires littéraires et sentimentaires" they published his collected works in thirty-four volumes at Vienna. Some other works: "Vie du Prince Eugène de Savoie. Lettre de Russie à la Marquise de Coigny"; "Lettres à Catherine II". His writings are full of wit but the style is incorrect and prolix.

29 LA GARDE-CHAMBONAS, 12-13.

30 A hill (484 meters) in the Eastern part of Vienna Woods.

31 La GARDE-CHAMBONAS, 66. 
Then they went to Isabey, to the famous painter who made a portrait of the Prince of Ligne. In December 1814 the Prince participated in a ball and he had there caught a cold. On 13 December 1814 he died. The funeral cortege was composed of eight thousand fantasists, and the representatives of the different arms. There were the general Tettenborn, ${ }^{32}$ Philip of Hesse-Homburg, ${ }^{33}$ the Prince of Richelieu, ${ }^{34}$ etc. And the convoy of the Prince of Ligne passed the crowned rulers, among them the King of Prussia and the Russian Tsar. The prince was buried in Kalemberg. ${ }^{35}$ With him an excellent expert of an eighteen-century Europe was gone for good and all.

Isabey, ${ }^{36}$ the famous painter went to Vienna to reproduce the main features of the celebrities who had arrived to the city of the Congress. His salon was in Leopoldstadt. By this time he was famous because he had painted the portrait of Marie-Antoinette and had become the painter of Napoleon I. He reproduced the portraits of the celebrities and the most beautiful women of the Empire of Napoleon. And it was him that organized and directed the holidays of this epoch in Paris. In Vienna he painted the portrait of the son of Napoleon dressed as a hussar. Isabey received a large number of orders from the celebrities in the Austrian capital. He made also a Congress by his paintbrush. It was Talleyrand who suggested Isabey to go to the Austrian capital. "A congress will open in Vienna. Go please!"37 The French diplomat wanted Isabey to paint a picture about the Congress of Vienna as had done Gerard Borch, also known as Gerard Terburg about the participants of the Peace Treaty of Münster in 1648..$^{38}$ And the picture was made by Isabey in 1819 under this title: Congress of Vienna. The painting presents the plenipotentiaries of the Congress with Metternich, Wellington, Castlereagh, Talleyrand, Labrador, the Spanish diplomat, Gentz, the secretary general of the Congress, etc. According to the original plan lord Wellington wouldn't have been included in the picture, because he arrived in Vienna in February 1815 to replace Castlereagh. For this reason, Isabey had to change the disposition of the picture and Wellington was placed in the corner of the painting as a newcomer to the Congress. Wellington was not satisfied with this. ${ }^{39}$

Prince Alexander Ypsilantis was one the friends of La Garde. We know well he came to be the first military and political leader of the Greek war of independence in 1821. He came from a Phanariot Greek family and his father was the hospodar of the Danubian Principalities. ${ }^{40}$ As a young man he went into Russian service making there a great career.

32 Friedrich Karl von Tettenborn (1778-1845), cavalry general in the Austrian and the Russian armies. He was a friend of La Garde and Prince of Ligne.

33 Philip, Landgrave of Hesse Homburg (1779-1846), in 1846 before his death he became the field marshal of the Austrian army.

34 Duke of Richelieu (Armand-Emmanuel de Vignerot du Plessis, 1766-1822), During the French Revolution and the Napoleonic era he was in exile and served in the Russian army as a volunteer. In 1803 he became Governor of Odessa. During the Bourbon restauration, 1815-1818 and 1820-1821, Prime Minister. Member of the French Academy from 1816.

35 LA GARDE-CHAMBONAS, 240.

36 Jean-Baptiste Isabey (1767-1855), a famous French painter. His master was Jacques-Louis David.

37 LA GARDE-CHAMBONAS, 113.

38 The title of this picture: "The Ratification of the Treaty of Münster", 15 May 1648.

39 LA GARDE-CHAMBONAS, 386.

40 The father of Alekxander Ypsilantis, Constantine Ypsilantis was the hospodar of Moldavia (1799-1802), the 
He was appointed by Alexander I his aide de camp in 1816. Vienna played an important role in the life of Ypsilantis. This city was his cradle of hopes in 1815 to liberate Greece from the Ottoman yoke. In March 1815 La Garde met Ypsilantis in the Prater, the large public park. It was the Prince who told La Garde that Napoleon had left Elba island. This news was sent from Florence to the English embassy in Vienna. Alexander I and his foreign minister, Karl Nesselrode were informed about this. For Ypsilantis this was a favourable moment to start working for the independence of Greece. He thought this dream would be a reality in a few years, because the Greek cause would be supported by the European people. Ypsilantis counted on the help of Capodistrias, ${ }^{41}$ the Russian Foreign minister to get the support of the Tsar. ${ }^{42}$ La Garde told Ypsilantis about his scruples: in his opinion the Ottoman Empire did not yet agonize. Recently La Garde travelled through the Empire and saw the signs of the vitality and the energy of this country. In his opinion, Europe would not take the risk of threatening the balance of power for the Greeks, for the country of Miltiades. ${ }^{43}$ As for Capodistrias, La Garde recognized he was the intermediary between Alexander I and Ypsilantis and the invisible supporter of the Greek cause until 1820. At that time there was a war between the sultan and Ali Pasha of Janina. This situation was a suitable moment for the members of the Filiki Eteria to appoint a leader to head their secret society. That post was offered to Ypsilantis and to Capodistrias, too. Ypsilantis accepted but Capodistrias refused it. La Garde met Ypsilantis for the last time in 1820 in Louisbourg, in Bavaria. On that occasion Ypsilantis was full of hope, because the first revolutionary wave after the Congress of Vienna started in Europe from Spain. This is the hour of emancipation for Greece - said Ypsilantis. He counted on the help of the Russian Tsar. But La Garde warned him: Russia had got Poland and the Tsar would like to get Constantinople, too, so Ypsilantis would have to help the Russian goals to be achieved. He adds that Capodistrias became the president of Greece in some years later and Ypsilantis died (1828) in Vienna, the city of his hopes. In spite of this Ypsilantis was found admirable by La Garde. ${ }^{44}$

It isn't easy to present all the famous personalities of the Congress, because, as I mentioned, the rulers of North Europe were all present in Vienna, and Western and Southern Europe sent the most important notabilities to the capital of the Habsburg Monarchy. In spite of the above-mentioned fact, I would like to present the Russian Tsar, Alexander I, based on the book of La Garde.

After the rulers had arrived in Vienna they agreed to arrange the ceremonial ranking on the basis of age. The Russian Tsar was born in 1777, the Prussian King in 1770, the Austrian Emperor in 1768, the ruler of Denmark in 1768, the King of Bavaria in 1756 and the ruler of Württemberg in 1754. But this ranking was used only on the festivities and not at official

hospodar in Walachia (1802-1806).

41 loannis Antonios Capodistrias (1776-1831) was born in Corfu and in 1809 went into Russian service. During the Congress of Vienna his task was to counterbalance the influence of Metternich. He was the first head of state in the independent Greece (1827-1831). In 1831 he was assassinated.

42 LA GARDE-CHAMBONAS, 404-407.

43 LA GARDE-CHAMBONAS, 403, 408.

44 LA GARDE-CHAMBONAS, 413-415, 418. Ypsilanti was defeated in Drăgăşani (Wallachia) in 1821. Between 1823 and 1827 he was imprisoned in Terezín (Theresienstadt), after that he was released due to the intervention of the Russian tsar, Nicholas I. He went to Vienna and died here in poverty. 
meetings because the rulers didn't participate in these deliberations. But the monarchs met each other every day one hour before supper to discuss the actual questions of the Congress. ${ }^{45}$

At the beginning of the Congress the monarchs gave each other various awards, decorations. And among them there were very interesting and bizarre ones, for example such as Black Eagle, Red Eagle, White Eagle, Elephant, the Wool, the Bath, etc. And they gave each other regiments too. Alexander I received from the Austrian Emperor the Hiller regiment and the flag of this regiment was embroidered by the Austrian Empress. The slogan of the flag: "Indissoluble union between Alexander and Francis". ${ }^{46}$ The Tsar paid damages to general Hiller for the loss of his regiment: the general received ten thousand forints from Alexander who paid one thousand forints also to all of the officers of the regiment. ${ }^{47}$

They talked much about the love affairs of Alexander but his lovers didn't cost him much. For example Demoiselle L..., a French actress received only some gold gifts from him. The underwear of the Tsar was made by Mrs Nariskin ${ }^{48}$ but he always forgot to pay for this. In the entourage of the Tsar we find the Grand Duke Constantin, the third personality of the Russian Empire, the Nariskins, Princess of Tour and Taxis, Prince of Koslowski, Baron Ompteda, Comtess of Tolstoy and Count of Tolstoy, Nowosiltzoff, counsellor of the Tsar and others. During the Congress the monarchs didn't stick to the etiquette. Alexander liked going to walk in the streets of Vienna and he was always very polite to everyone. At one time at the Prater, he helped his colleague, the Austrian Emperor, to get off the horse and he received the acclamation of the crowd. ${ }^{49}$ La Garde-Chambonas recalled a conversation between Talleyrand and Alexader I about Saxony based on the memoir of Talleyrand. The Tsar promised Saxony to the King of Prussia adding that the King of Saxony was a traitor. Talleyrand disputes the qualification of the Tsar saying that he could not call a king a traitor. ${ }^{50}$

One day the Tsar gave a reception on the occasion of his sister Catharine's birthday in the palace of the Prince of Razumowski. All the monarchs and other illustrious guests of the Congress were invited. They danced mazurkas, Russian and other dances ${ }^{51}$ Alexander loved to dance, he loved the festivities and he loved beautiful women and he understood the jokes. One day an officer of the Russian Navy arrived in Vienna with a dispatch to the Tsar. But he didn't know Alexander. The Tsar was walking around the palace in a simple

45 Russia was represented by Count of Nesselrode, Prince of Rasoumoffsky; France by Prince of Talleyrand and Prince of Dalberg; Prussia by Prince of Hardenberg; Austria by Prince of Metternich; Great-Britain by Vicomte Castlereagh, Prince of Wellington; Bavaria by Prince of Wrede; Württemberg by Count of Wintzingerode; Spain by Knight of Labrador; Portugal by Count of Palmella; Sicily by Alvaro Ruffo; Naples by Prince of Campochiaro. LA GARDE-CHAMBONAS, 28, 32-33. FLASSAN, Gaetan de Raxis de: Histoire du congrès de Vienne. Acte général du 9 juin 1815. Annexes etc. par l'auteur de la diplomatie française, tome III., Paris 1829, 4-11.

46 LA GARDE-CHAMBONAS, 28-29.

47 LA GARDE-CHAMBONAS, 30.

48 The Nariskin family was in a close relationship with the Russian tsar's family. The mother of Peter the Great was from this family. Mr. Nariskin went to Vienna with Empress Elisabeth and Alexander I gave him fifty thousand rubles to organise the travel of his wife.

49 LA GARDE-CHAMBONAS, 31.

50 LA GARDE-CHAMBONAS, 190.

51 LA GARDE-CHAMBONAS, 200-201. 
dress and when they met each other the officer asked him where to find the Tsar. "He is not in the palace - answered Alexander - but you will find him in two hours." Then they began to talk and after a while Alexander introduced himself: "I am Alexander, the Russian Tsar. You can give me the dispatch." The officer started laughing. "This is a bad joke" - he said. "I am the emperor of China" - was his reply. Finally the marine handed the telegram to the Tsar who invited him to dinner. ${ }^{52}$ But Alexander could be also hard. His brother, the Grand Duke Konstantin (viceroy of the Kingdom of Poland) was in Vienna, too. At one time he conducted the military exercises of the regiment of Prince Windischgrätz. The soldiers were in front of the Danube. Konstantin commanded them to march and because the soldiers were not far from the river, the regiment almost sank into the Danube. Seeing this danger Prince Windischgrätz commanded the soldiers to stop. The Grand Duke thought he was in Russia and he could look on the soldiers as his toys. This event was a joke for him, but not for Alexander. The Tsar sent him away from Vienna. In a Hungarian hussar officer's opinion, Miklós Jósika, ${ }^{53}$ Alexander I was a handsome man and one of the most loveable monarchs in Vienna. ${ }^{54}$

\section{Everyday Life in Vienna}

The Congress Vienna was full of beautiful ladies. We mention some members of the European aristocracy: the Princess of Tour and Taxis, Countess of Bernsdorff, Princess of Hesse-Philippstal, Countess Theresa Appony, Princess Sapieha, Princess Lichsteinstein, Countess of Kohari, Princess Esterhazy, Princess Mary Esterhazy, Countess Zamoïska, Countess of Potocki, Countess Batthyany, Lady Castlereagh, and others and, of course, the wives of the monarchs as the Austrian and the Russian empress. The Congress was a high festivity in honour of the European peace. The Festivals Committee organized fancydress balls in the Burg, at the Imperial Palace and the ladies toilette was very graceful and dazzlingly rich.

The Austrian Emperor opened the palace to his illustrious guests. The palace in the Burg was the residence of two emperors, two empresses, four kings, a queen, two heirs to the throne, a prince imperial, a crown-prince, two grand duchess and three princes. The family of the Austrian Emperor moved to the Schönbrunn Palace. The Viennese were proud of their city to become the capital of Europe. Supplying with food the guests of the Imperial Court cost fifty thousand forints for a day. The celebrations costs of the Congress amounted to forty million francs. Every day there were banquets, concerts, balls, masquerades, hunts. The rulers met each other every day. The guests of Vienna tasted the Hungarian, Italian and Rhine wines. And they tasted the Hungarian Tokai wine, too. A lot of foreigners lived in the suburbs and the housing price was very high. Foreigners were welcomed warmly in

52 LA GARDE-CHAMBONAS, 335-338.

53 Jósika, Miklós (1794-1865), Hungarian nobleman, baron, journalist, writer, a representative of Hungarian romantic literature. He participated in the Napoleonic wars and became a captain. He had landed properties in Transylvania and Szabolcs County. In 1818 he finished his military service and lived from his lands while participating in the world of literature. He wrote several novels. He took part in the Hungarian war of independence in 1848-1849 and after that he went into exile. He died in Dresden.

54 JÓSIKA Miklós, Emlékirat, online: http://mek.oszk.hu/04900/04984/04984.pdf, 109. 
Vienna. But there was one condition: it was not allowed to talk about the government and to take action against it. If someone violated this condition, he was ordered to go the next day to the police station. Here they told him very politely that his passport was wrong, so he had to leave Vienna. ${ }^{55}$

During the Congress, the secret police kept everyone under suveillance, and the foreigners were under special shadowing. When a foreigner arrived in Vienna he was registered at the police. ${ }^{56}$ The secret police observed the correspondence of the members of the imperial family, and the activities, the correspondence of the representatives of the great powers were observed, too. ${ }^{57}$

The police department of the state was founded by Joseph II in 1782. The first leader of this organisation, the State Department of the Interior, was Count of Pergen. The Emperor founded the secret police in 1786 and the main goal of this police was to support the Emperor and the state. Francis II created the Police Department in 1792 with Pergen at its head. ${ }^{58}$ The French police in Paris served as a model for Pergen to organise the police system in the Habsburg Monarchy. ${ }^{59}$

Despite the actions of the police and the secret police the Viennese and the participants of the Congress enjoyed themselves. There were celebrations in the Burg, Prater, Kohlmarkt, Graben and on the Kärtner street. The literary men, critics, actors, writers and the young officers met in Lothringer which was a beer-house. At that time life was very expensive in Vienna. Jósika tells us that an invitation to the imperial ball cost twenty forints and a hussar captain's wages for a month was eighty forints. ${ }^{60}$ The very interesting masked balls were organised in the Imperial Redoute. One of the brightest entertainments was the sledging, and all the monarchs took part in this game. The imperial sledges were very splendid, ornate. The guests of Vienna could make trips to the green, to the Mödling valley, to the Helena valley. Around the capital there were many beautiful gardens. Jósika presents also some interesting and beautiful dames. In his opinion the most beautiful was Prince Kohary's daughter, a blonde lady. Among the beautiful ladies Countess Hojos, the sisters of Alexander I, the Princess of Weimar and the Princess of Oldenburg are mentioned. Jósika writes also about the actresses. Among them Demoiselle Adamberger was the most beautiful and the most honest. At that time she was in love with Körner, the German poet. Jósika mentions two young actresses, Walla and Laucher and among the singers, Madam Catalani and Demoiselle Burgondio. In Jósika's opinion, Vienna was a great theatre in 1815,

55 LA GARDE-CHAMBONAS, 7, 19, 26-28, 32, 260.

56 GEBHARDT, Helmut: The police reform of Joseph II in the provincial capitals of Austria, online: http://irhis. recherche.univ-lille3.fr/dossierPDF/CIRSAP-Textes/Gebhardt.pdf, 6.

57 They observed the correspondence of Marie-Louise, Talleyrand, Castlereagh, Nesselrode, Czartoryski, Wellington, Stein, the King of Saxony, etc. WEIL, Maurice-Henri: Les dessous du Congrès de Vienne d'après les documents originaux des archives du Ministère impérial et royal de l'intérieur à Vienne. Tome premier (juin 1814 - 4 janvier 1815), Paris 1917, XXII.

58 The leaders of the police: 1792-1803, Count Pergen; 1803-1807, Baron Sumeraw; 1812-1816, Baron Hager (1807-1812, he was the vice president of the police); 1817-1848, Count Sedlnitsky (1815-1817, he was the vice-president). In 1848, the Police Ministry was abolished. WEIL, XX.

59 GEBHARDT, 2; WEIL, XIX.

60 JÓSIKA, 116. 
where everyone played some kind of role. ${ }^{61}$

La Garde's book and Jósika's memoir don't inform us about the great political and diplomatic events which took place in the capital of the Habsburg Monarchy in 1814-1815. They show the everyday life of the monarchs, the most important personalities of the Congress of Vienna. That's why these books are very interesting resources for the historian.

\section{Abstract}

This study presents an interesting memoir about the Congress of Vienna. La GardeChambonas, a French aristocrat, went to Vienna in 1814 to participate in the life of the city during the Congress. This book is a very good source for getting acquainted with the life of the European aristocracy in the capital of the Habsburg Monarchy. The author of the memoir presents a lot of personalities, rulers as Alexander I of Russia, Isabey, the famous painter and others. But first of all he writes about Prince of Ligne, his patron in Vienna. Before the presentation of the life in Vienna, the study deals with some questions of organisation regarding the Congress.

\section{Keywords}

balance of power, peace and stability, legitimism, Holy Alliance, Quadruple Alliance, House of Bourbon, Metternich, La Garde-Chambonas, Prince of Ligne, Alexander I of Russia, Francis I, Emperor of Austria, balls, festivities

\section{References}

BÉRENGER, Jean: Histoire de l'Empire des Habsbourg 1273-1918, Paris 1990.

BREUNIG, Charles: The Age of Revolution and Reaction 1789-1850, New York - London 1977.

BOURGEOIS, Emile: Manuel historique de politique étrangère, tome II. Les révolutions (1789-1830), Paris 1933.

CAPEFIGUE, Baptiste: Le congrès de Vienne dans ses rapports avec la cirsconscription actuelle de IEurope: Pologne, Cracovie, Allemagne, Saxe, Belgique, Italie, Suisse, 18141846, Paris 1847.

Correspondance inédite du prince de Talleyrand et du roi Louis XVIII pendant le Congrès de Vienne publiée sur les manuscrits conservés au dépôt des Affaires étrangères avec préfaces, éclaircissements et notes par M. G. PALLAIN, Paris 1881.

DROZ, Jacques: L'Europe centrale. Évolution historique de l'idée de "Mitteleuropa", Paris 1960. FLASSAN, Gaetan de Raxis de: Histoire du congrès de Vienne. Acte général du 9 juin 1815. Annexes etc. par l'auteur de la diplomatie française, tome III., Paris 1829. 
FLEURY, Maurice: Notice sur Le Comte Auguste de La Garde - Chambonas, in: Souvenirs du Congrès de Vienne 1814-1815 publiés avec introduction et notes par le Comte Fleury, LA GARDE-CHAMBONAS, Auguste Louis Charles de, Paris 1901, VII-XV.

GEBHARDT, Helmut: The police reform of Joseph II in the provincial capitals of Austria, online: http://irhis.recherche.univ-lille3.fr/dossierPDF/CIRSAP-Textes/ Gebhardt.pdf.

GILDEA, Robert: Barricades and Borders. Europe 1800-1914, Oxford 2003.

JÓSIKA Miklós, Emlékirat, online: http://mek.oszk.hu/04900/04984/04984.pdf.

LA GARDE-CHAMBONAS, Auguste Louis Charles de: Souvenirs du Congrès de Vienne 1814-1815 publiés avec introduction et notes par le Comte Fleury, Paris 1901.

MAJOROS, István: Fejlődési utak a 19. századi Európában I. A gazdaság átalakul, Pécs 1995.

NICOLSON, Harold: The Congress of Vienna: A Study of Allied Unity, 1812-1822, New York 1946.

ORMOS, Mária - MAJOROS, István: Európa a nemzetközi küzdőtéren. Felemelkedés és hanyatlás 1814-1945, Budapest 1998.

PONTEIL, Félix: Histoire général contemporaine. Du milieu du XVIIle siècle à nos jours, Paris 1973.

SCHROEDER, Paul W.: International politics, peace, and war, 1815-1914, in: The Nineteenth Century Europe 1789-1914, BLANNING, T. C. W. (ed.), Oxford 2000, 158-209.

SCHROEDER, Paul W.: The Transformation of European politics 1763-1848, Oxford 1994. URBÁN, Aladár (ed.): Nyugat-Európa és Amerika 1789-1918. Új-és legújabbkori történeti szöveggyújtemény 1/1, Budapest 1970.

WEIL, Maurice-Henri: Les dessous du Congrès de Vienne d'après les documents originaux des archives du Ministère impérial et royal de l'intérieur à Vienne. Tome premier (juin 1814 - 4 janvier 1815), Paris 1917. 